\title{
Analysis of Paralytic Shellifsh Poison and Tetrodotoxin by Ion-Pairing High Performance Liquid Chromatography
}

\author{
Yuji Nagashima,*1 Junichi Maruyama,*2 Tamao Noguchi,*2 \\ and Kanehisa Hashimoto*2 \\ (Accepted August 30, 1986)
}

\begin{abstract}
An ion-pairing high performance liquid chromatographic method using a silica ODS column was developed for analysis of paralytic shellish poison (PSP) and tetrodotoxin (TTX). As mobile phase is used a mixture of $0.05 \mathrm{M}$ phosphate buffer ( $\mathrm{pH} 7.0$ ) containing $2 \mathrm{~mm}$ heptanesulfonic acid/methanol $(99: 1)$ for separation of gonyautoxins and TTXs, and the one $(75: 25)$ for separation of saxitoxins. PSP and TTX members thus separated were detected as fuorogenic substances, by heating with a periodate reagent (for PSP), or with $3 \mathrm{~N} \mathrm{NaOH}$ (for TTX).
\end{abstract}

Paralytic shellfish poison (PSP) is a potent marine neurotoxin produced mainly by dinoflagellates belonging to the two genera Protogonyaulax and Pyrodinium. These plankton, especially in a bloom, infested to bivalves which, in turn, cause human poisonings through careless ingestion. PSP had long been considered to be synonymous with saxitoxin (STX), but now is demonstrated to be composed of more than ten components inclusive of STX whose structures closely resemble each other.

In Japan, a nationwide PSP-monitoring system has been established, and commercially important bivalves are periodically assayed for toxicity to prevent toxic specimens or products from marketing. The toxicity is assayed by the official method using mice, ${ }^{1)}$ which is convenient but of low accuracy. In addition, it cannot give any information on toxin composition, nor distinguish PSP from other neurotoxins such as tetrodotoxin (TTX). In this connection, some marine animals have been found to contain both PSP and TTX simultaneously, ${ }^{2,3)}$

In a previous paper, ${ }^{4)}$ we proposed a high performance liquid chromatography (HPLC) method for PSP and TTX, using an ion exchange resin. However, it did not satisfactorily separate gonyautoxin-5 $\left(\mathrm{GTX}_{5}\right)$ and gonyautoxin- $6\left(\mathrm{GTX}_{8}\right)$ from other PSP members.

In this situation, we have developed a reversedphase ion-pairing HPLC method using hepta- nesulfonic acid as counterion, which can be applied to PSP as well as TTX.

\section{Materials and Methods}

\section{Toxin Preparations}

GTX $_{1-4}$ were isolated from digestive glands of the scallop Patinopecten yessoensis, ${ }^{5,8)} \mathrm{GTX}_{\mathrm{B}}$ and epi-GTX ${ }_{8}$ from those of the oyster Crassostrea gigas, ${ }^{7)}$ and STX and neoSTX from the crab Zosimus aeneus, $\left.,{ }^{8},{ }^{2}\right)$ as reported previously. All these preparations, along with $\mathrm{GTX}_{5}$ and $\mathrm{GTX}_{8}$ which were kindly given by Dr. S. Hall, U.S. Food and Drug Administration, were used as toxin standards. On the other hand, toxin extracts were prepared from the mussel Mytilus edulis as reported previously, ${ }^{10)}$ and used to check the applicability of the newly developed method.

TTX and anhydroTTX*3 preparations were isolated from ovaries of the puffer Fugu vermicularis porphyreus, as reported previously, ${ }^{1.2}$ and used as toxin standards. In addition, tetrodonic acid was prepared ${ }^{12)}$ and used similarly. A liver extract was also prepared from the puffer Fugu niphobles and used as a test sample.

\section{HPLC System}

Fig. 1 shows a schematic diagram of the HPLC system for PSP and TTX. The system was composed of a Hitachi 638-50 HPLC and a 650-10 spectrofluorometer equipped with an $18 \mu \mathrm{l}$ micro-

*1 Department of Food Technology and Engineering, Tokyo University of Fisheries, Konan, 4-5-7, Minato, Tokyo 108, Japan (長島裕二: 東京水産大学食品工学科).

*2 Laboratory of Marine Biochemistry, Faculty of Agriculture, University of Tokyo, Bunkyo, Tokyo 113, Japan (丸山純一, 野口王雄, 㛢本周久: 東崇大学露学部水産化学研究室).

*3 T. Noguchi et al., unpublished. 


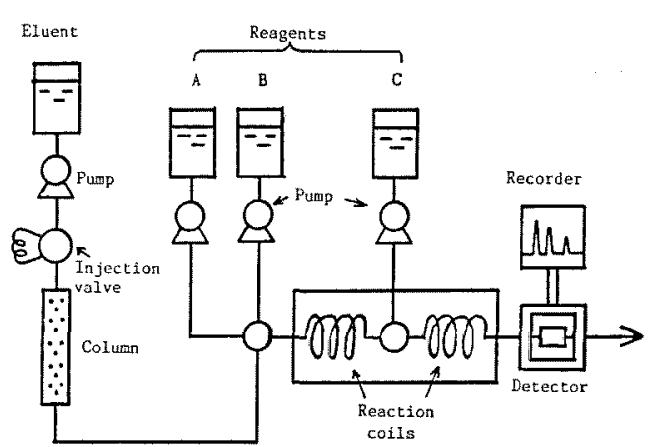

Fig. 1. Schematic diagram of HPLC system.

flowcell. A $300 \times 6 \mathrm{~mm}$ (I.D.) silica ODS column (YMC AM-314, Yamamura Kagaku) was used. The reaction system consisted of three reagent reserviors and two reaction coils $(7 \mathrm{~m} \times 0.3 \mathrm{~mm}$ I.D. and $10 \mathrm{~m} \times 0.3 \mathrm{~mm}$ I.D.).

\section{Mobile Phase}

Mobile phases were provided by mixing $0.05 \mathrm{M}$ phosphate buffer (pH 7.0) containing $2 \mathrm{mM}$ heptanesulfonic acid (HSA) and methanol at 99:1 $(\mathrm{v} / \mathrm{v})$ for separation of GTXs or TTXs, and at 75:25 (v/v) for separation of STXs. The former and latter mixtures thus provided are referred to as "solvents 1 and 2", respectively, hereafter.

\section{Reagents for Detection of Toxins}

Three reagents were used to detect PSP: (A) $0.05 \mathrm{M}$ periodic acid, (B) $0.2 \mathrm{~N} \mathrm{KOH}$ plus $1 \mathrm{M}$ ammonium formate in $50 \%$ formamide, and (C) $1 \%$ chloroacetaldehyde in $1 \mathrm{M}$ citrate buffer $(\mathrm{pH}$ 4.0). On the other hand, $3 \mathrm{~N} \mathrm{NaOH}$ was used to detect TTXs.

\section{Chemicals}

All chemicals were of analytical grade unless otherwise noted. Sodium salts of pentanesulfonic acid (PSA), heptanesulfonic acid (HSA) and decanesulfonic acid (DSA) were obtained from Aldrich Chemicals (Milwaukee, WI) and used without further purification. HPLC grade methanol and acetonitrile were supplied by Wako Pure Chemicals (Osaka).

\section{Chromatographic Procedures}

All the operations were performed at room temperature unless otherwise specified. One to five microliters of sample solution was injected through the injection valve with a $200 \mu l$ loop. The mobile phase was pumped isocratically at a

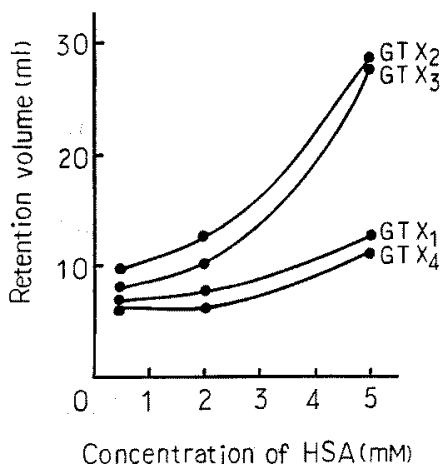

Fig. 2. Effect of heptanesulfonic acid concentration on the separation of GTXs.

flow rate of $1.0 \mathrm{~m} l / \mathrm{min}$.

Detection of PSP was performed as described by Nagashima et al. ${ }^{13)}$ Briefly, the eluate from the column was first reacted with an oxidant $(0.05 \mathrm{M}$ periodic acid) and a base $(0.2 \mathrm{~N} \mathrm{KOH}$ plus $1 \mathrm{M}$ ammonium formate in $50 \%$ formamide), and then the fluorescence intensity of the resultant mixture was increased by mixing with $1 \%$ chloroacetaldehyde in $1 \mathrm{M}$ citrate buffer ( $\mathrm{pH} 4.0)$. These fluorescence reactions were performed in a $65^{\circ} \mathrm{C}$ water-bath. The intensity of fluorogenic substance obtained was monitored at $390 \mathrm{~nm}$ with $336 \mathrm{~nm}$ excitation.

On the other hand, TTX and related substances were detected by mixing $3 \mathrm{~N} \mathrm{NaOH}$ with the eluate at a $1: 1$ ratio, followed by heating at $100^{\circ} \mathrm{C}$ for $0.4 \mathrm{~min}$, and monitoring the fluorescence at $505 \mathrm{~nm}$ with $381 \mathrm{~nm}$ excitation.

\section{Results and Discussion}

Before the above described method was attained, HPLC behaviors of PSP components were compared under a variety of conditions. Behaviors of GTXs clearly differed from those of STXs which were retained more strongly on the column. $\mathrm{Re}$ sults of those experiments, along with some examples of analysis of toxin extracts, are described below.

\section{HPLC Analysis of Gonyautoxins}

The effect of HSA concentration on the retention volume of GTXs was examined, using solvent 1. As shown in Fig. 2, the higher the HSA concentration, the larger the retention volume of each GTX component. However, GTX $_{2}$ and GTX $_{8}$ showed a poor resolution at $5 \mathrm{~mm}$. Replacement of the counterion by PSA or DSA resulted in a 


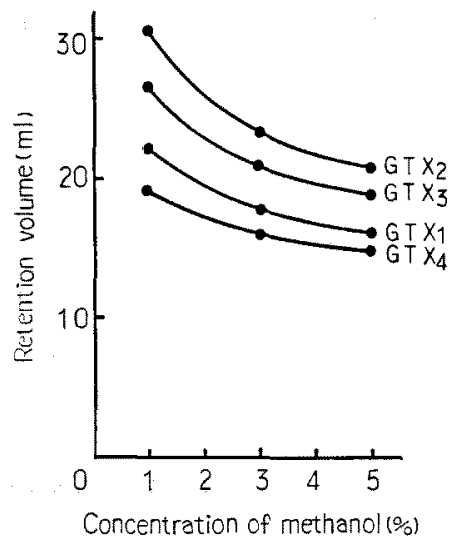

Fig. 3. Effect of methanol concentration on the separation of GTXs.

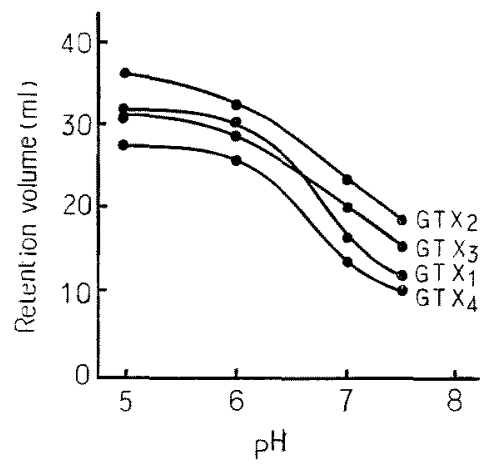

Fig. 4. Effect of the pH of mobile phase on the separation of GTXs.

poorer resolution of these GTXs (data not shown). From these results, $2 \mathrm{~mm}$ HSA was judged to be best for mutual separation of GTXs.

In the next place, the effect of methanol concentration on the mutual separation of GTXs was examined, using solvent 1 and two other solvents which consisted of the $0.05 \mathrm{M}$ phosphate buffer containing $2 \mathrm{mM}$ HSA and methanol (97:3 and 95: 5). As shown in Fig. 3, the mutual separation tended to become poor when methanol proportion was increased. In addition, acetonitrile did not improve the separation when used in place of methanol. Therefore, solvent 1 was selected as the mobile phase.

The effect of $\mathrm{pH}$ of mobile phase on the mutual separation of GTXs was examined using the $0.05 \mathrm{M}$ phosphate buffer containing $2 \mathrm{~mm}$ HSA. The results obtained are shown in Fig. 4. GTX $_{1}$ and $\mathrm{GTX}_{3}$ showed close retention volumes below
Table 1. Recommended HPLC conditions for separation of PSPs and TTXs

\begin{tabular}{|c|c|}
\hline Column: & Silica ODS column $(6 \times 300 \mathrm{~mm})$ \\
\hline Temperature: & Room temperature \\
\hline Mobile Phase: & \\
\hline Solvent 1 & $0.05 \mathrm{M}$ phosphate buffer $(\mathrm{pH} 7.0)$ \\
\hline $\begin{array}{l}\text { (for GTXs } \\
\text { and TTXs) }\end{array}$ & $\begin{array}{l}\text { containing } 2 \mathrm{mM} \text { HSA and } \\
\text { methanol }(99: 1)\end{array}$ \\
\hline $\begin{array}{l}\text { Solvent } 2 \\
\text { (for STXs) }\end{array}$ & $\begin{array}{l}0.05 \mathrm{M} \text { phosphate buffer (pH } 7.0) \\
\text { containing } 2 \mathrm{~mm} \text { HSA and } \\
\text { methanol }(75: 25)\end{array}$ \\
\hline Flow Rate: & $1.0 \mathrm{~m} / / \mathrm{min}$ \\
\hline
\end{tabular}

$\mathrm{pH}$ 6.0. This phenomenon could be explained as follows. Each of N-1 hydroxy toxins such as GTX $_{1}$, GTX $_{4}$ and neoSTX has a pKa value at around 6.8 , which corresponds to N-1 hydroxy group. ${ }^{14)}$ Two other pKa values of each toxin correspond to two guanidino groups. ${ }^{15,16)}$ At pH 7-8, GTX or $_{2} \mathrm{GTX}_{3}$ has a net charge of +1 , whereas $\mathrm{GTX}_{1}$ or $\mathrm{GTX}_{4}$ is neutralized by the dissociated N-1 hydroxy group. Below $\mathrm{pH} 6$, the $\mathrm{N}-1$ hydroxy group of $\mathrm{GTX}_{1}$ or $\mathrm{GTX}_{4}$ does not dissociate, resulting in their chromatographic behaviors close to those of $\mathrm{GTX}_{2}$ or $\mathrm{GTX}_{3}$. In contrast, GTXs were satisfactorily separated from each other at $\mathrm{pH} 7.0$, or to a lesser extent at higher pH. The best HPLC conditions for GTXs thus attained are summarized in Table 1.

Similar experiments were not carried out on $\mathrm{GTX}_{5}$ and $\mathrm{GTX}_{3}$, due to scarcity of the sample available. In some limited experiments, however, both GTXs were found to be separated from each other and from other GTXs when chromatographed under these conditions, as described below.

\section{HPLC Analysis of Saxitoxins}

STXs were found to be eluted by solvent 2 , but not by solvent 1 . The effect of HSA concentration on the mutual separation of both STXs was examined. Both components were separated better at higher HSA concentrations (Fig. 5), but both peaks in HPLC tended to become dull, and hence $2 \mathrm{~mm}$ was judged to be the best concentration of HSA.

Then, the effect of methanol concentration was examined. As shown in Fig. 6, the mutual separation of STXs tended to be poor at higher concentrations, and in addition, both chromatographic peaks become dull in $20 \%$ methanol. The effect of $\mathrm{pH}$ on the separation of STXs was examined to find $\mathrm{pH} 7.0$ to be best (data not shown). 


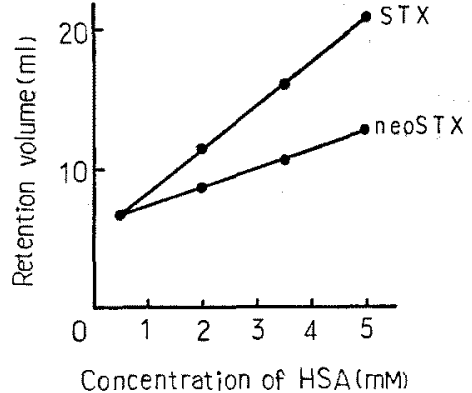

Fig. 5. Effect of heptanesulfonic acid concentration on the separation of STXs.

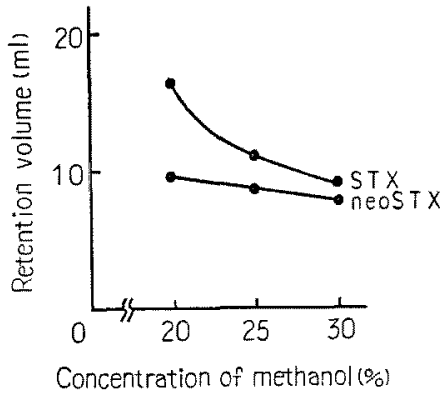

Fig. 6. Effect of methanol concentration on the separation of STXs.

From these results, solvent 2 (the $0.05 \mathrm{M}$ phosphate buffer containing $2 \mathrm{mM}$ HSA and methanol, $75: 25)$ was selected as the mobile phase for separating STXs. The best HPLC conditions for STXs based on these results are summarized in Table 1.

\section{HPLC of Reference Standards of PSP}

A mixture of $\mathrm{GTX}_{1-B}$ standards was subjected to the present HPLC under these conditions, resulting in satisfactory mutual separation (Fig. 7, left). GTX, was eluted prior to $\mathrm{GTX}_{4}$, and GTX $_{5}$ was between $\mathrm{GTX}_{1}$ and $\mathrm{GTX}_{6}$, suggesting that the retention volume of a sulfocarbamoyl toxin generally is somewhat smaller than that of the corresponding nonsulfated toxin. Both of GTX $_{8}$ and its epimer were separated from other toxins, but eluted as a single peak with a retention volume of about $7 \mathrm{ml}$ (Fig. 7 , inset).

HPLC of STX standards with solvent 2 resulted in a good separation of neoSTX and STX (Fig. 7, right).

\section{Application of HPLC to Mussel Extract}

HPLC patterns of toxin extract from mussel

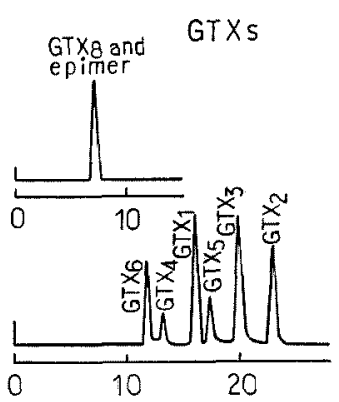

Retention volume (m),

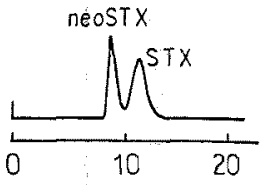

Retention volume(m)

Fig. 7. HPLC of standard mixtures of GTXs (left) and STXs (right).

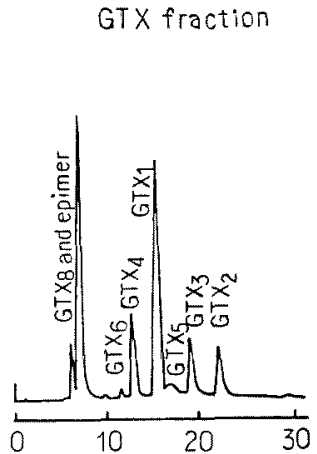

Retention volume(mi)

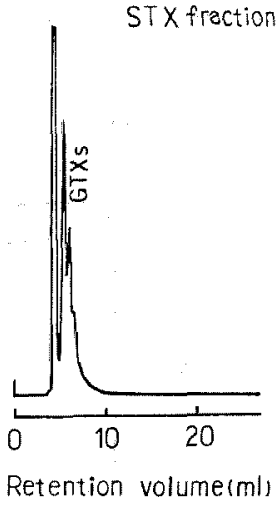

Fig. 8. HPLC of "GTX fraction" (left) and "STX fraction" (right) from mussel digestive gland.

digestive gland are shown in Fig. 8. Mussel toxins were demonstrated to be consisted mainly of 11-hydroxysulfate toxins $\left(\mathrm{GTX}_{1-4}, \mathrm{GTX}_{8}\right.$ and its epimer), along with $\mathrm{GTX}_{6}$ and $\mathrm{GTX}_{6}$ as the minor components. STXs were hardly detected.

\section{HPLC Analysis of Tetrodotoxin and Related Substances \\ The conditions for mutual separation of GTXs were found to be applied successfully to TTX and related substances (Fig. 9). Incidentally, the detection reagent for TTX and related substances did not react with any PSP components at all, and TTX and related substances with the detection reagents for PSP neither. This means that one and the same toxin extract can be analyzed for both PSPs and TTXs.}

Fig. 10 shows an example of application of this HPLC method to puffer liver extract. The toxin in the extract was consisted mainly of TTX and 


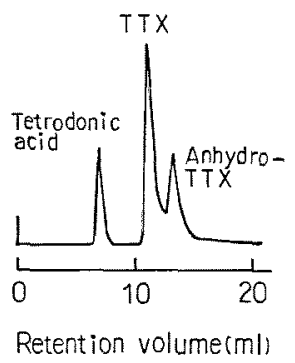

Fig. 9. HPLC of a standard mixture of TTX and related substances.

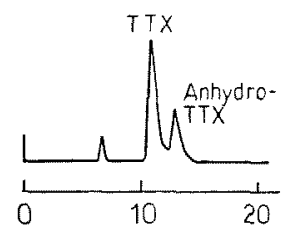

Retention volume (ml)

Fig. 10. HPLC of a toxin preparation from liver of puffer Fugu niphobles.

anhydroTTX.

The reversed-phase ion-pairing HPLC method developed here is convenient, rapid, accurate and sensitive, and is applicable to PSPS as well as TTX and related substances.

\section{Acknowledgments}

The authors express sincere thanks to Dr. S. Hall, U.S. Food and Drug Administration, for kindly giving specimens of GTX $\mathrm{GX}_{5}$ and GTX. The present study was supported in part by a Grant-inAid from the Ministry of Education, Science and Culture, and a research fund from the Institute of Physical and Chemical Research.

\section{References}

1) Environmental Health Bureau, Ministry of Health and Welfare (ed.): Shokuhin Eisei Kensa Shishin (Shokuhinbetsu), Nippon Shokuhin Eisei Kyokai, Tokyo, 1978, pp. 240-244.

2) T. Noguchi, A. Uzu, K. Koyama, J. Maruyama, Y. Nagashima, and K. Hashimoto: Nippon Suisan Gakkaishi, 49, 1887-1892 (1983).

3) M. Kodama, T. Ogata, T. Noguchi, J. Maruyama, and K. Hashimoto: Toxicon, 21, 897-900 (1983).

4) Y. Onoue, T. Noguchi, Y. Nagashima, K. Hashimoto, S. Kanoh, M. Ito, and K. Tsukada: J. Chromatogr., 257, 373-379 (1983).

5) T. Noguchi, Y. Ueda, K. Hashimoto, and H. Seto: Nippon Suisan Gakkaishi, 47, 1227-1232 (1981).

6) T. Noguchi, M. Kono, Y. Ueda, and K. Hashimoto: J. Chem. Soc. Japan., 1981, 652658 (1981).

7) Y. Onoue, T. Noguchi, J. Maruyama, K. Hashimoto, and H. Seto: J. Agric. Food Chem., 31, 420-423 (1983).

8) T. Noguchi, S. Konosu, and Y. Hashimoto: Toxicon, 7, 325-326 (1969).

9) K. Daigo, A. Uzu, O. Arakawa, T. Noguchi, H. Seto, and K. Hashimoto: Nippon Suisan Gakkaishi, 52, 309-313 (1985).

10) Y. Onoue, T. Noguchi, J. Maruyama, Y. Ueda, K. Hashimoto, and T. Ikeda: Nippon Suisan Gakkaishi, 47, 1347-1350 (1981).

11) H. Narita, T. Noguchi, J. Maruyama, Y. Ueda, K. Hashimoto, Y. Watanabe, and K. Hida: Nippon Suisan Gakkaishi, 47, 935-941 (1981).

12) T. Goto, Y. Kishi, S. Takahashi, and Y. Hirata: Tetrahedron, 21, 2059-2088 (1965).

13) Y. Nagashima, T. Noguchi, Y. Onoue, and K. Hashimoto: Nippon Suisan Gakkaishi, in press.

14) Y. Shimizu, C. P. Hsu. W. E. Fallon, Y. Oshima, I. Miura, and K. Nakanishi: J. Am. Chem. Soc., 100, 6791-6793 (1978).

15) E. J. Schantz, J. M. Lynch, G. Voyvada, K. Matsumoto, and H. Rapoport: Biochemistry, 5, 1191-1195 (1966).

16) R.S. Rogers and H. Rapoport: J. Am. Chem. Soc., 102, 7335-7339 (1980). 